\section{BIOSPHERE RESERVES AS "LEARNING SITES" FOR EDUCATION FOR SUSTAINABLE DEVELOPMENT}

\section{PLENARY PRESENTATION ON THE DECADE OF EDUCATION FOR SUSTAINABLE DEVELOPMENT: THE PERSPECTIVE FROM A CANADAIAN BIOSPHERE RESERVE, BY RICHARD MURZIN, NIAGARA ESCARPMENT BIOSPHERE RESERVE}

We are in the first year of the United Nations Decade for Sustainable Development. This declaration identifies Biosphere Reserves as places for learning.

UNESCO rightly identifies education as a lifelong process - of young people and of adults alike. It is a process of empowerment. In the words of Mr Franz Morak, Austria's State Secretary for Arts and Media, it is education "that seeks to balance human and economic well-being with cultural traditions and respect for the earth's resources." As citizens of the world, we must learn constantly - about ourselves, our potential, our limitations, our relationships, our society, our environment, our world. Education for sustainable development is a life-wide and lifelong endeavour which challenges individuals, institutions and societies to view tomorrow as a day that belongs to all of us, or it will not belong to anyone. Biosphere Reserves are perfectly positioned to take up this challenge - at many levels and in many forms. Our effectiveness is rooted in the close connection we have locally. Local connections are our main strength. This is why UNESCO has turned to us for our views, assistance and leadership at this pivotal moment for our planet and its people.

We know that education for sustainable development concerns all kinds of educational structures and learning situations. It can happen in our schools, across the full range of subject areas and curricula including the sciences and the arts.But how do all these general concepts fit into activities of a Biosphere Reserve? In my own Biosphere Reserve, the Niagara Escarpment in Ontario, Canada, we try to cover a spectrum of educational institutions. We have elementary and secondary school teachers leading groups of students who monitor the environmental situation of local lakes, rivers and forests. At the mature level of institutional education, we sponsor an accredited field course in monitoring for university students in their third year of study.

For the Biosphere Reserve, we also coordinate a research conference every two years. This is attended by more than 250 researchers, community members, industry representatives, government people and other interested people from our Biosphere Reserve and Biosphere reserves across Canada. This has gone on for more than 12 years, and we are always impressed by the strong interest of nonresearch people in natural and social research.

I would also like to briefly mention two emerging trends, beyond the academic framework, that we are most interested in, for the Niagara Escarpment and for other Canadian Biosphere reserves. The first is education for advocacy. Increasingly, processes guiding the location and shape of development become so complex or so expensive, that citizens consider themselves unable to participate. Governments are fond of saying they plan to streamline or simplify these processes. Unfortunately, in my experience, this is usually done to make the process faster for the developer or exploitive industry.Let me give you an example of what I mean by "education for advocacy." In 1998 in my Biosphere Reserve, a pilot project was launched by a broad coalition of environmental and recreational groups to create a citizen's guide for the Niagara Escarpment Biosphere Reserve. It is called "Protecting the Niagara Escarpment: A Citizen's Guide." The guide clearly and concisely describes how people can become involved in helping to shape development in our area. It tells people about the area and why it is important. But more to the point, it tells citizens how to engage in informal and formal processes, part of political and legal processes, and even how to use the news media.

As you know, the role of a Biosphere Reserve is to serve as a demonstration area for sustainable devel- 
opment. Indeed this model of a citizen's guide was extended last year to our entire province of 12.5 million people, including urban areas. The provincial guide is entitled: "A Smart Future for Ontario - how to protect nature and curb urban sprawl in your community." It is also available free on the internet.This example showed me a couple of things. Firstly, I saw an emerging trend in public education toward increasing the capacity of citizens to participate in decision-making processes for sustainable development. This is a revival of democracy. Furthermore, it reinforces my awareness of how a Biosphere Reserve can function as a demonstration area for an approach that can be applied on a larger scale. In this case, what began in our Biosphere was a model for the rest of our province.

The second emerging trend for public education in resource conservation is a growing realization that health and health care costs are the meeting point between the environment and the economy. In Canada, we are engaged in a national debate about how best to maintain our government-sponsored health care system. In my province of 12.5 million people, health care consumes $45 \%$ of our publicsector budget spending. Yet the average waiting time for surgery or to see a medical specialist is 18 weeks and, without more money, we are about to lay off thousands of nurses and health care workers. In our country, as in others, obesity is on the rise. For the first time in the history of mankind, there are more people dying from eating too much than from famine. A U.S. study from March 2005 states that the current generation of American young people is the first in history who will live shorter lives than their parents due to weight-related health problems. The Ontario College of Family Physicians, an organization representing family doctors in my province, released a study this year that reviews the illness costs of suburban development, or urban sprawl. The study outlines the effects of certain kinds of residential development on respiratory disease, cardiac disease, obesity, diabetes, automobile and pedestrian mortality, cancer, stress-related illnesses, family life and work performance. Where statistics are available, the report also speaks about the costs related to these outcomes. This work, and a companion study being prepared on our west coast, suggest that many of these health problems and expenses can be avoided by designing communities where walking is a viable alternative to using an automobile.

These are things that people understand - health and money.

Although we do not yet have a demonstration project on this trend, I consider that there is potential for the Biosphere Reserve approach. In fact, at the Niagara Escarpment, and through our national network, we plan to use this data to educate people about the benefits of sustainable development for health and health care cost avoidance. That will make it easier for us to promote sustainable development - development that does not encroach on core natural areas and the agricultural countryside of our Biosphere Reserve.

If we can find funding - and I am certain that we will - we plan to encourage research that makes connections between the environment, health and health care costs. I predict that this kind of data will be one of the main themes that we will be promoting in our public education programs in Canadian Biosphere Reserves. I would be interested to hear if any of you, as my colleagues, have experience in this area. 


\section{PLENARY PRESENTATION ON THE UK MAB AND BRAUNTON BURROWS PERSPECTIVE ,BY ANDY BELL}

All of the Millennium Development Goals adopted by the UN impact on the concept of sustainable development as we understand it. Most documents and strategies acknowledge that the key component to the delivery of Sustainable Development lies in education. The Seville Strategy for Biosphere Reserves highlights the logistic function and the sustainable development function, which, if my previous statement is correct, education is implicit in both of those functions.

Most of you will be aware that the Decade of Education for Sustainable Development formally launched in March 2005 and will end in December 2014 and UNESCO has placed MAB in the front line for implementing the strategy. I will come back to this later.

My first key question is. What is Education for Sustainable Development? "Education for sustainable development has come to be seen as a process of learning how to make decisions that consider the long-term future of the economy, ecology and equity of all communities. Building the capacity for such futures-oriented thinking is a key task of education." This statement reinforces the notion that progress toward sustainability requires education that cultivates respect for diversity, more caring relationships between humans and the natural world, and more environmentally and socially responsible forms of development.

This implies a complex picture and not just environmental education. Obviously we need to know what Education for Sustainable Development is but we have to grasp that the aim is not only about the understanding of what sustainable development is, but what the issues are and looking at the development of solutions with the appropriate audiences. My advice is not to be distracted too long by redefining the topic but concentrate on the process of planning and delivering its implementation.

Within the UK the delivery of Education for Sustainable Development is not yet strategically recognised in all sectors, though it is growing. For example although it refers to a wider vision, Department for Education and Skills strategy only applies within the formal sectors and not in the informal education sector that is left for others to fill so it would seem. There are other agencies looking for resources to fill those gaps.

UK MAB is still developing its education strategy in response to the frameworks being established by UK Government, and is identifying the gaps where the Network (people and places) can add value. Where possible there will be an advocate for Biosphere Reserves on the key national panels dealing with Education for Sustainable Development. The committee will also implement strategic actions to support the UK Network and its links to the wider Biosphere Reserve network.

At the local level, The Braunton Burrows vision for education is very ambitious. The analysis of our strategies for the management of protected areas tend to bring out a very large number of actions that related awareness raising, education and interpretation rather than direct implementation of "throwing money" at the problem. That is not to eliminate the "sense of now": education is for now and for the future.

Considering Schools first; the junior school curriculum now supports Education for Sustainable Development very well. The schools inspection system has changed in the last few months to include specific areas of investigation about the schools performance on Education for Sustainable Development.

As a Reserve we are assisting schools to meet the needs of the national curriculum and the added elements required under the new inspection regime, such as wildlife areas within school grounds or other sites close to the schools which they adopt as theirs to manage.

An action being developed at the moment is the Biosphere Reserve Junior Guardian Scheme. This will have sections that include activities not just on wildlife but also re-cycling, energy, waste and some global awareness stimulated through the Biosphere Reserve Network. 
For the older students; it seeks to support the establishment of a University College in the area that will deliver a range of Foundation degrees (2 years of a bachelor degree) related to management of the Biosphere Reserve area. Not only does this bring an economic activity to the area as a "knowledge industry" but also reduces the net outward migration of young people from the area.

We are seeking to develop modules of Sustainable Development to be included in vocational training, such that a person training in a diploma in hairdressing will receive some training in sustainable development. The college will also deliver lifelong and extramural learning for the even older students.

With regard to specialists, we hope to establish a new field research centre and education visitor facility in the Reserve area called the Oceanic Centre. This is intended be on a redundant water-side site and will be constructed using strict sustainable construction principles. The Oceanic centre will be a facility that will be for education, research and interpretation.

It will be linked to a new academic institute based in Liverpool and its network of 600 scientists specialising in integrated water and land management; it will link to North Devon College and Bideford College Higher Education and Further Education facilities, Exeter and Plymouth Universities, relating to the topics covered within the core expertise of the Oceanic Centre: environmental sciences, oceanography, marine science, surf science, marine biology and hydrology. The centre will also demonstrate sustainable exploitation of the oceans for food, minerals, energy and recreation, ideally linking to other coastal and marine Biosphere reserves in the world wide network.

On informal or non-formal learning, we have just produced a draft interpretation strategy that will support the learning in the non-formal sectors. The themes of the strategy are based on what is special about the area such as its biodiversity, culture, geodiversity, maritime heritage and our place in the world. The strategy highlights the need to use a large variety of media: person to person, electronic, printed, on-site panels and the arts (where we have some positive experience). There is a wealth of local literature that has highlighted some of the issues and has stimulated local pride and in the region. The most famous of which is "Tarka the Otter."

Over the last 5 years we have commissioned over 350,000 Pounds of artwork in the environment. These have been sculptures, performances and films. All of which have touched public in ways we never imagined and were designed to bring the viewer to see their environment from a different perspective. These have stimulated communities to take a stewardship role in looking after the environment in their immediate area.

The Decade of Education for Sustainable Development brings special opportunities and responsibilities for Biosphere Reserves. The Decade's strategy closely reflects the Seville Strategy. I would just like to bring to your attention some of the ideas we are pursuing in the UK with MAB as what we hope is only part of our contribution to the Decade. MAB are working with TVE film production company to produce a series of short clips or vignettes for different reserves in the world-wide network. They will be combined into one programme that will broadcast in different time-zones by BBC World. There should be 2 wins: demonstration of real sustainable development in action and promotion of awareness of Biosphere Reserves.

In the UK, a local environmentalist based in Braunton Burrows has written a short (10 minute) film that helps people to understand the concept of sustainability on a local scale and that we all live downstream of someone else's actions. The script is now being worked into a proposal for a film company to produce.

Seminars and Continuing Professional Development are being developed. The first of which is the proposed quality economies seminar directed at stakeholders within all of the UK's Biosphere Reserve regions.

A final suggestion that is being gently pursued is to commission an opera written specifically to highlight the issues of sustainable development and, we hope, some solutions. Because it is coming form North Devon, a title has been suggested as "Tarka the Opera" 
I will end this presentation with 2 further questions with no real answers or elaboration from me. Is there a defined scope of Education for Sustainable Development that Biosphere Reserves should deal with specifically, is every Biosphere Reserve different? The world of Education for Sustainable Development is vast as shown in the UNECE strategy. To deliver any Education for Sustainable Development effectively there has to be some focussed area of activity that complements and integrates to a wider delivery framework. As Albert Einstein said "Any fool can make something complicated. It takes a genius to make it simple." What is the focus for each of the Biosphere Reserves, are they common or different enough to represent the whole delivery framework. For example, are gender equality issues more prevalent in Rhone Biosphere Reserve than in Braunton Burrows, or is climate change more acute in coastal reserves than in mountain areas?

What are the opportunities for Euro MAB-wide collaboration on decade of Education for Sustainable Development to develop a UNESCO-wide action? I look forward to the debate in the workshops and will listen intently and participate enthusiastically; I am, after all, here for my education too.

\subsection{WORKSHOP SESSION RESULTS}

MODERATOR: Pavlo Cherinko, MAB Ukraine

\section{WORKSHOP PARTICIPANTS:}

1. Pavlo Cherinko (Ukraine) - moderator;

2. Stan Boychuk (Canada);

3. Peter Cupa (Czech Republic);

4. Georgi Ekov (Bulgaria);

5. Goran Gugič (Croatia);

6. Lia Rosenberg (Estonia);

7. Jan Vybiral (Czech Republic);

8. Mykhailo Zhmud (Ukraine).

\section{CASE STUDIES PRESENTED:}

1. Jan Vybiral, Peter Cupa "Presentation of Lower Morava Biosphere Reserve".

The report informed that presently the global network of BR works is an important link between countries. BRs are often considered to be the only institutions which can save the original ecosystems. It necessary to stress that the question of the conservation is a pressing issue mostly for those reserves which are located on the territories of less developed countries. We can try to improve the situation by making higher investments into education, using BRs as living classrooms and model areas. We are to support a new generation of experts by enabling more students from developing countries to get inspiration from sustainably managed European cultural landscape. The richest part of the world should take financial responsibility for obtaining the space for intensive exchange of all vital information.

2. Mykhailo Zhmud "The Danube BR as the Learning Site for Sustainable Development of the Ukrainian Danube Delta". The report informed that studying socio-economic development of the local community is the basic condition for the sustainable development of the BR's region in the former USSR. Ecotourism development in the BR's region is the most perspective type of activity for the local community. 
National commercial use of the reed resources in the Danube Delta BR is the basis of the economic development of the Delta area.

3. Goran Gugič "Towards wise use in Lonjsko Polje Nature Park, Croatia.

The park's example revealed the co-existence of the tasks of preservation and rational nature use with the conservation of the main traditional principles of land use, stock-raising business as well as the traditional handicraft industry. Studying socio-economic development of the local community is the basic condition for the sustainable development of the region. That's why the park may be considered as the "learning site" for education for sustainable development.

4. Stan Boychuk made two reports: "Presentation of the Clayquot BR (Canada)" and "A network of research and education venues to promote $a$ new research and education economy". The participant informed that learning put such questions as:

- an inclusive model of governance including regional participants, some of them are from outside the boundaries of the BR;

- a consensus model of decision-making;

- stakeholder engagement and reengagement. Learning can't provide for.

- first nation or aboriginal involvement as primary participants in the process from inception and as equal decision-makers;

- a commitment to the ecological integrity of the ecoregion;

- a belief that our ancestors do not want us to suffer failure.

After each report there were many interesting questions as well as fruitful and constructive discussions.

\subsection{WORKSHOP SESSION RESULTS}

MODERATOR: Valérie Meyer, Vosges du Nord BR, France

RAPPORTEUR: Catherine Cibien, MAB France

\section{CASE STUDIES PRESENTED:}

- Education and training in biosphere reserves, some proposals for EuroMAB - Valérie Meyer, Vosges du Nord BR, France.

- Aspects of interdisciplinary approach in international schools network of Park Škocjanske Jame - Vanja Debevec Gerjevic, Park Škocjanske jame, Slovenija.

Targets: schools, scientists, general public...

Objectives

- Knowledge: observe and understand

- Skills: learn and know-how

- Attitudes: protect and admire

- Involve inhabitants (pupils, parents, grandparents, communities) through education activities

- BR recognized as learning sites for ESD

Educational activities:

- Teacher training

- Monitoring involving schools and other public

- A multitude of local projects based on local resources...

Networking:

- Exchange ideas, methods, materials, information on projects

- Consolidate the existing material

- Create new material defining sustainable development in BR

- Develop school twinnings

\section{PROPOSALS FOR EUROMAB}

- UNESCO website

- Consolidate and share the materials: tools and actions

- Platform for organising school twinnings

- UNESCO - BBC World Cooperation (4mm films on 12 BRs on sustainable development)

A possible slogan: "Learning to love, Learning to live, Learning to last" 


\section{CASE STUDIES}

\section{EUROPEAN BIOSPHERE RESERVES - LIVING CLASSROOMS FOR SUSTAINABLE DEVELOP- MENT, BY JAN VYBIRAL, LOWER MORAVA BIOSPHERE RESERVE, CZECH REPUBLIC}

In present times the global network of biosphere reserves works as an important link between countries of the whole world. There is no doubt that in some parts of the world a biosphere reserve is often the only institution which enables us to save the last remnants of original ecosystems as a biological reserve for mankind's needs.

History teaches us that people can exploit and destroy natural resources at an alarming rate. It is a sad rule that in areas once covered by developed civilizations we usually find deserts today. Deforest-ation, extensive farming, soil salinization and loss of soil's fertility - all of that brought about the end of many developed civilizations.

Grazing and forest burning are the main factors in the destruction of original ecosystems even at present. In many parts of the world the area of such ecosystems is critically small. The situation on tropical islands is symptomatic. Madagascar is a typical example. The fourth largest island of the world has 14 million inhabitants and ranks among the most amazing natural environments. Its endemic plant and animal species make up around 90 per cent of the total biodiversity. However, today less than 15\% remains from the original areas covered by virgin forest ecosystems. This negative development continues and it is in mankind's own interest to look for and find a solution for how to stop it as soon as possible.

It is necessary to accept the notion that the question of nature conservation is a pressing global issue mostly for those who are lucky enough to be living in the richest part of the world. We know that investment in education has the highest return. Biosphere reserves are primarily designed as places supporting nature conservation but also as places where intensive exchange of experience, support of sustainable land use and education of both young people and specialists takes place.

Let us remember that the most of the original European forest ecosystems was destroyed several centuries ago. We have learned a lesson which might be a solution for developing countries as well - to plant and cultivate man-made forests while using autochtonous tree species. The developed cultural landscape of Europe where both forests and agrocenoses are represented and where sustainable forest management and farming are a rule came as a result of understanding that we can peacefully coexist with landscape and nature. European biosphere reserves thus can serve as "living classrooms" where sustainable development is taught.

The rich countries should take the responsibility and enable more young students and scientists from developing countries to get inspiration from the wisely and sustainably managed European cultural landscape. This will enable them to solve problems in their countries themselves while getting effective help from us. The areas of biosphere reserves should then provide the space for intensive exchange of all vital information.

If we enable more young Europeans studying natural sciences and subjects related to land use (e.g. forestry) to gain first-hand experience of real conservationist issues of our planet in developing countries, maybe a new generation of experts will grow up. These new managers of European and global institutions will find mechanisms which will slow down and stop the inevitable crisis of world's natural ecosystems.

A long and difficult journey begins. A journey made meaningful by the challenge which the pampered European biosphere reserves might be lacking. The Lower Morava Biosphere Reserve is doing its best to take its share of responsibility. 


\section{THE DANUBE DELTA BIOSPHERE RESERVE AS A "LEARNING SITE" FOR SUSTAINABLE DEVELOPMENT OF THE REGION, BY MICHAEL ZHMUD, UKRAINE}

The Danube Biosphere Reserve (DBR) is situated in the southwestern part of Ukraine. It is bordered in the east by the Black Sea, and in the south by the Kiliya Branch of the Danube River, which forms the border between Ukraine and Romania. The DBR includes the Sea Delta of the Kiliya Branch, Zhebrianski Range natural complex, StensovskoZhebriyanski Plavni wetland complex and Yermakov Island. The approximate geographical coordinates of

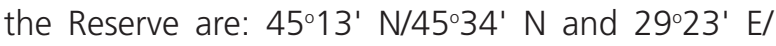
29०46' E.

The total area of the DBR is $50,252.9$ ha including 2 $\mathrm{km}$ of the Black Sea zone: permanent use as protected area: 23,957 ha, without retirement from main land use: 26,295.9 ha; zonation: core area: 14,904 ha, zone of regulated protected regime: 7,811 ha, buffer zone: 19,392 ha, zone of anthropogenic landscapes: 8,145.9 ha.

Its management infrastructure is monitored by the National Academy of Sciences of Ukraine; managed by a special administration headed by a director; state supervision of compliance with the environmental legislation: Ministry of Nature of Ukraine. In terms of biodiversity, there is a total of 953 species of higher vascular plants, of which from the Red Data Book of Ukraine - 18 species, from the European Red List - 3 species. The flora of the DBR includes a significant number of plants used for fodder (about $50 \%$ of all plant species), or having medicinal, ornamental and other uses. About 300 species (nearly one-third of the total) are adventives plants that were introduced by man, mostly from the American Continent. A total of 263 bird species is registered: from the Red Data Book of Ukraine 42 species, from the European Red List -7 species. It has about $78 \%$ of all bird species in the Danube Delta, $62 \%$ of all bird species recorded in Ukraine and $67 \%$ of all bird species from Red Data Book of Ukraine. The most important birds from European Red List in the DBR are: Dalmatian pelican, red- breasted goose, white-tailed eagle and slender-bill Curlew. A total of 39 mammal species is registered, from the Red Data Book of Ukraine.

- 13 species, from the European Red List - 6 species. The most important mammals from the European Red List in the DBR are: European Mink and European Wild Cat. A total of 11 amphibian species and 6 reptile species were registered. A total of 99 fish species were registered from the Red Data Book of Ukraine

- 17 species from the European Red List - 9 species.

Tradional economic activities and their perspectives:

\section{FISHERIES:}

- Basic directions: freshwater fishery and migratory Danube herring

- Fish stocks have distinctly declined because of overhunting, especially freshwater species

- Quantity of the workplaces decreasing

- Economical reimbursement falling

- In the future the industry is likely to continue its decline

- Temporary advice from the Reserve authority

\section{MARKET GARDENING:}

- Main crops: the strawberry, the grapes and the apples

- Proportion in the pressure of work of the population slightly increase

- Economical reimbursement insignificant

- Because of the low effectiveness of the labor the importance of the industry will decrease

\section{CATTLE BREEDING:}

- Basic directions: partly wild breeding of cattle and horses

- Share of the economy is insignificant

- Industry is in decline for a variety of reasons

- Development prospects are insignificant

\section{HUNTING:}

- Basic direction - game-shooting for waterfowl birds

- Importance by way of additional source of food 
for the local population is minimal

- Prospect of development is only towards hunting tourism

- Temporary advice from the Reserve authority

\section{LOCAL USE OF REEDS:}

- Basic directions: by way of household fuel, by way of constructional material

- Capacities of use and economical importance are minimal at present

- In the next decades the only prospect is its use as a roofing material, chiefly for tourist facilities

\section{NAVIGATION:}

- After the embargo against Yugoslavia the deepwater way Danube Black Sea was lost. Shipping intensity declined sharply and about $80 \%$ of workplaces were lost.

- Problems of the waterway down the Bystroye branch: immediate prospects are unclear

- In more distant future hope for a revival of the industry and more jobs

\section{LOCAL INDUSTRY:}

- Basic directions: ship repair, fish processing, machine-building

- Only one of the 4 enterprises is operational - the ship repair plant

- Order books declined by $80-85 \%$

- Significant revival of the given direction is unlikly

\section{TRADITIONAL EMPLOYMENT AND POPULA-} TION:

- Level of unemployment reachs a threatening scope: $60-80 \%$

- Prospects of more employment from traditional economical activities insignificant

- Population decline by $20-25 \%$, especially ablebodied adults and children

- Increased pressure on the natural resources of the delta, first of all on the fish resources

- Sharpening of the socio-ecological conflicts

Sustainable development in the Ukrainian Danube Delta region: The use of reeds is the most important element.

\section{HISTORICAL BACKGROUND:}

Season 1998-1999 - the first Ukrainian roofing reed was sent to the Netherlands, involving 70,000 reed bundles

Season 1999-2000 - 2 local companies working in reed harvesting, exported about 250,000 reed bundles

Season 2000-2001 - the first reed harvester appeared in the region

Season 2002-2003 - 4 local companies working in reed harvesting with 3 reed harvesters, exported about 450,000 reed bundles

Season 2003-2004 - 4 local companies working in reed harvesting with 4 reed harvesters, exported about 750,000 reed bundles

Season 2004-2005 - 5 local companies working in reed harvesting with 5 reed harvesters, exported about 950,000 reed bundles

Season 2005-2006 - more than 10 local companies preparing for reed harvesting with 6 reed harvesters Unused reserves: commercial reclamation of dense reed resources and utilization of the waste products and ill-conditioned reed in the form of fuel briquettes

\section{SOCIO-ECONOMIC ASPECTS:}

- More than 1,000 seasonal and constant jobs created in the reed-harvesting business, i.e. more than a half of all employment in winter

- Social situation of the local population improv ing, increased revenues for local budgets

- Pressure on the traditional resources of the delta is decreasing, first of all on the fish stocks

- Level of criminality among the local population is falling

\section{ECOLOGICAL ASPECTS:}

- Annually, 10,000 tons of dead organic mass are extracted from the Delta ecosystem, to improv the ecological situation

- Reed beds are growing, improving their biological capacity and biodiversity

- Reduced risk of illegal and ecologically dangerous burning of reed bed sites 
Plenary Presentation and Workshop Results

CHAPTER IV

Development of different forms of ecological tourism

Basic kinds of tourism in the Danube Delta:

- Green tours. the top category, serving up to 8,500 tourists per year

- Foreign cruise tourism - ranks second in tourist volume, up to 6,000 per year

- Fishing and hunting tourism - small in number at present, but with sustainable growh prospects

- Bird-watching tourism - very promising, but still small-scale

- Scientific tourism - new for the delta, but with an encouraging future

Tourist information center of the Reserve with a museum of nature and nature use in the delta about 3,6000 visitors per year

Lower Danube Region tourist information center about 1,2000 visitors per year, own bilingual website

\section{SOCIO-ECONOMICAL ASPECTS}

- More than 95 constant and seasonal work places were created

- Additional market for the local production (fish, fruits, wine, etc.)

- Economical base for the development of the local souvenir industry

- Additional means for the preservation of the original appearance of Vilkovo town (Ukrainian Venice), the center of ecological tourism in the region

- Additional revenues for the local budget

- Positive socio-economical image of the Lower Danube Region and particularly the Reserve

\section{ECOLOGICAL-EDUCATIONAL ASPECTS}

- Increasing the level of ecological education of the population

- Disseminating an understanding of the essence and aims of the biosphere reserves among the population

- Growing authority of the Reserve among the local population
- Growing understanding of the economical value of the nature conservation establishments among the authorities and population

- Assistance for a better image of the Reserve in general both inside the country and abroad 


\section{TOWARDS WISE USE IN LONJSKO POLJE NATURE PARK, CROATIA (A POTENTIAL BIOSPHERE RESERVE), BY GORAN GUJIC}

The Ramsar site and important bird area Lonjsko Polje Nature Park $\left(510 \mathrm{~km}^{2}\right)$ represents mainly palustrine-riverine wetlands located within the floodplains of the Middle Sava river basin (Central Posavina, Croatia). It represents the largest maintained inundation area of all the Danube-river catchment area and, at the same time, the key facility of the flood control system of the entire Sava river basin (including Bosnia and Hercegovina and Serbia and Montenegro).

Within the Pan-European Biological and Landscape Diversity Strategy, the World Conservation Union (IUCN) identified the site as a showcase of Best Practices of Conservation Planning in Rural Areas of CEE countries. Recently, DEG-TDCC's Regional Tourism Master Plan recognised LPNP as the unit selling point for tourism development of continental Croatia.

The high-ranked species and habitat diversity is mainly caused by man-made landscape variety, traditional grazing activities with endangered autochthonous breeds and a natural micro-relief created by natural flood dynamics. Since the Sava river became international, effective flood control and conservation management demand an integrated approach. To achieve its overall objectives: (1) to maintain and protect the biological and landscape diversity of Lonjsko Polje Nature Park, (2) to improve the benefits for local people, (3) to raise public awareness and knowledge of ecological and cultural values of the site, and (4) to ensure effective flood control on a (multilateral) basin scale, LPNPPS started to develop consultative processes and appropriate structures of involvement of stakeholders and local people on a park scale in the frame of its LIFE00/TCY/CRO/0076 project. With the outputs of this project, LPNPPS created the basis to spread its capcities on a basin scale and to support the (Interim) Sava River Basin Commission. The Service sets up Ramsar's wise use and integrated river basin management approach (1) by developing consultative processes and appropriate structures which involve the various stakeholders for the conservation, utilisation and management of the water resources by ensuring non-structural flood control methods which take advantage of the natural functions of wetlands to supplement or replace existing flood control infrastructure, (2) by developing a management planning process for Lonjsko Polje Nature Park according to the provisions of Croatia's Nature Protection Act and Ramsar's Frameworks for managing Wetlands of International Importance taking into account the wider context of Central Posavina-scale management processes, and interacting with these processes so as to ensure that the needs of the wetland are recognized and fully incorporated in this wider planning and management, (3) by providing support and tools for the effective implementation of Posavina's wetland-related traditional wise use activities to improve benefits for local people, (4) by providing Lonjsko Polje Nature Park and its surroundings with a sustainable visitor management system based on DEG-TDCC's Regional Tourism Master Plan, (5) by improving the knowledge and skills of ranger staff of Croatia's protected areas and protected areas located in the Sava River Basin on basic ecology, communication, interpretation and monitoring. 


\section{EDUCATION AND TRAINING IN BIOSPHERE RESERVES: SOME PROPOSALS FOR EUROMAB, BY VALÉRIE MEYER, VOSGES DU NORD BIOSPHERE RESERVE, FRANCE}

Education, training and teaching are basic missions for biosphere reserves. They are recognized as learning sites for education for sustainable development (ESD) by UNESCO.

French biosphere reserves work within a national network with people involved in this field.

The presentation of this case study is built in three parts and concerns the ten French biosphere reserves:

- some examples of education in each BR,

- the national working group on education and training in BRs,

- proposals for EUROMAB.

Luberon Biosphere Reserve realises a yearly programme of educational activities on Biosphere Reserves for teachers. A scheme has been developed to be given to teachers to present and explain the concept of biodiversity, Biosphere Reserves and to propose activities for pupils.

Fontainebleau Biosphere Reserve organises training programs for trainers: sessions for teachers about biosphere reserves: environmental, cultural, socioeconomic aspects...

Vosges du Nord Biosphere Reserve develops tools for education on sustainable development based on local resources. The main objective of this program is to increase the understanding of the capacity of the territory. A "Park Corner" has also been installed at some colleges to be a BR information point about sustainable development and to get in one point all the information and books about this subject.

In France, education for sustainable development has been part of official teaching programs since September 2004. This is a very positive aspect of the context for ESD and the place and role of biosphere reserves in this field.

The ten French biosphere reserves have formed a working group and a network to exchange and share experiences, knowledge, ideas and methods. This group meets often to reinforce partnerships among biosphere reserves, also to involve partners and to lobby at local and national level.

Some proposals are made to involve the BR network and to help all the French BRs. For example, a training session for teachers on biodiversity is being prepared for use in the ten French BRs.

Twinning of BR schools is offered each year to make classes working together from one BR to the other. In order to communicate its activities, the working group has made some communication tools, posters and leaflet in French and English. These tools are available and can be requested from the French MAB office.

The French working group has some proposals to provide to the EuroMAB network and could be a good method to develop partnerships, exchanges and involvement between BR inhabitants:

- developing schools twinnings at the EuroMAB level between biosphere reserves,

- propose an easy monitoring activity to schools (migratory bird arrival and departure, flowering time...) between BR schools,

- in the twinning context: 2 schools work in different countries on the same monitoring activity. 


\section{ASPECTS OF INTERDISCIPLINARY APPROACH IN INTERNATIONAL SCHOOLS OF THE PARK ŠKOCJANSKE JAME, SLOVENIA, BY VANJA DEBEVEC GERJEVIC.}

Sustainable development is presented as a recommendation for implementation of management plans in the areas that are outstanding for their natural and cultural heritage and regions or countries as well.

Presented thoughts in the paper should bring forward the complexity of such sustainable development and underline the importance of pedagogic knowledge that should act as a key factor in forming the proper concept of society development and monitoring the impacts in presenting the solutions for proper adaptations in modern society.

Our efforts have been devoted to a special approach to environmental education. With an aim to achieve long-term goals, special attention is being paid to the young. The most important issues here are nature-oriented education; encouraging participation in politics and economy; stimulating tolerance and respect, responsible behaviour and capacity to make the best use out of one's knowledge. After the international project in 2000, we have established an international schools network of the park. Its function and projects will be presented as well.

The Park Škocjanske jame - Škocjan Caves, Slovenia is located on classical karst, at the interface of limestone and flysch, where the Reka River in over the millennia carved out an extraordinary caves system, collapsed dolinas, sinkholes and one of the biggest underground canyons in Europe.

On 27 November 1986 the Škocjan Caves were listed as a world natural and cultural heritage UNESCO. In 1996 the Regional park Škocjan Caves was established by the government of the Republic of Slovenia. A public service agency was installed as the park authority in 1997 and the mission of nature protection, interpretation of natural and cultural heritage in order to preserve them for future generations finally started.

Along with the underground canyon of the Reka
River, the Škocjan Caves were assigned as Ramsar wetland of international importance in 1999.

On 29 October 2004, Park Škocjanske jame, Slovenija, was accepted in the international network of biosphere reserves and thus became a MAB locality as The Karst Biosphere Reserve.

In order to promote the World Heritage Site a strong emphasis was put on education programmes in the park. During the years the high efficacy of its impact has been proven in public awareness and participation of local people (Debevec, 2004).

The core zone with surrounding areas was submitted to the first scientific research, which explained and described the karst features. Nowadays we can find Slovene expressions in regular use by experts in karstology. Škocjan Caves is a system of eleven caves, two collapsed dolinas, natural bridges and sinkholes. Its underground chambers and canyon are distinguished by the volume and astonishing forms of the stalactite formations. In the underground world we can find some rare and endemic species, which together with interesting flora and fauna of collapsed dolinas contribute a great deal to the biodiversity of the park in general. Cultural heritage is also very important for the site, since it represents the rich history that left behind many archaeological finds, and a tradition of mining, sawing and mills along the Reka River.

Activities performed by the park according to guidelines for nature protection and conservation, public awareness, education and training, enables the park and its inhabitants to represent a reference point for the karst region as whole. The most important activity, which is planned on many levels, is water protection. The karst surface is extremely vulnerable due to its specific geological structure. Based on cultural heritage the general care for water is constantly present. Proper and pedagogically well established education is the key to meet the challenges of economic progress and sustainable development (Debevec, 2003).

Anyhow the global meaning of sustainable development cannot be limited to planned teaching, but it is necessary to ensure also a parallel moment of an 
education process that forms values. Knowledge, which is accepted as holistic cognition and value, has its meaning in its underlying basis for personal growth. Education has an instructive meaning, if there are reasons or cognition of certain facts transmitted in educative process. That is why specialised, non-personal and technically focused knowledge of objects by itself has little educative value. Personal and socially generic focused knowledge has an optimal role in education (Novak, 1990).

Besides including local inhabitants in activities of the Park Škocjanske jame, Slovenija, we pay attention to public awareness and communication in the buffer zone and transitional area as well. Working with young people is one of priorities in the park. Park Škocjanske jame, Slovenija established the schools network of the park in 2003. It linked schools from the buffer zone and core area in Slovenia and also elementary schools from Italy. They were previously included in the Phare project of the park, titled: "The Reka River from the mountains to the sea". The Network enables the exchange of experiences of pedagogic workers in the field of education and training, presentation of the park and international conventions UNESCO and Ramsar and MAB programme to the pupils. School children are able to participate in different research projects of the park with social or naturalistic content. The Network also provides for the performance of schools activities in public, which participate to improve he quality of social and intergenerational relations.

The international schools network of the park includes schools that are located along the Reka River flow, from its springs above the caves to the sea: Elementary school Podgora, Kuteževo; Elementary school Anton Žnideršič, llirska Bistrica; Elementary school Dragotin Kette, Ilirska Bistrica; Elementary school dr. Bogomir Magajna, Divača; Elementary school dr. Bogomir Magajna, Vreme; Elementary school Pinko Tomažič, Trebiciano, Italia; Scuola Media de Marchesetti, Sistiana, Italia.

The schools network is formed on the basis of joint work and co-operation of local people and experts in karstology, biology, ecology, forestry, archaeology,

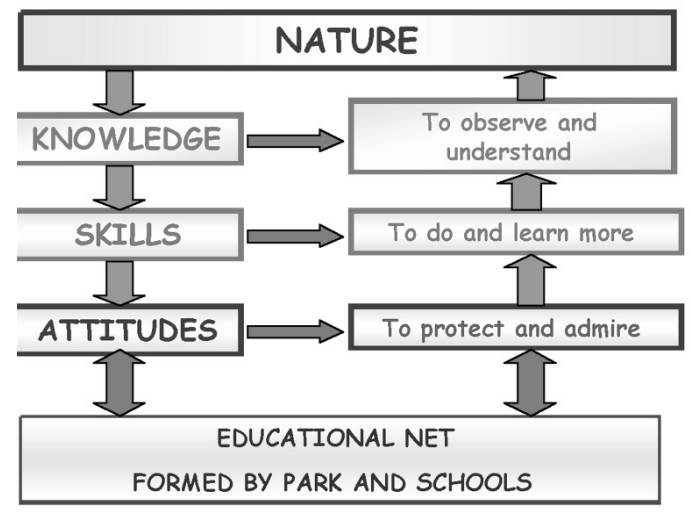

Figure 1: Basic concepts of schools network of the park Škocjanske jame

ethnology, architecture, history, language science and other interdisciplinary branches.

Work of the network and presentations of progress and results have outstanding value in public awareness. Water in the karst presents a key element in the formation of surface karst features, caves and dolinas. Respect for water determined the range and ways of anthropogenic impact in nature. Man in the past was forced to adapt to modest and scarce water resources.

Wells, karst ponds, ice pits and saws are a heritage from the past that represents through its functions a basis for sustainable development. Nowadays we can explore their biodiversity and importance in preserving the cultural heritage heritage for the development of natural values. Interconnections of man, nature and culture through time can be transferred by carefully planned educational programmes, which involve children and parents, adult inhabitants and visitors of the park.

Besides gaining knowledge of environment and society, the network offers a possibility in cognition of Slovene and European nature and society. With a proper education programme it plays an important role in creating the responsible attitude and knowledge in fulfilling the tasks of nature protection and conservation of natural and cultural heritage.

The schools network Park Škocjanske jame, Slovenija, has prepared an interdisciplinary programme "Observing for knowledge". It includes several research projects for schools in the park net- 
work, where children perform chemical and biological analysis of water in the Reka River and various types of wetlands. These data are then completed with meteorological data of each location and in the final phase an interpretation of results is provided by the park. Especially the final phase is crucial because it is important for understanding the very professional and official data and at the same time it provides a vision of their applicability. One of the interesting projects is also the bioindication of ozone where the interdisciplinary approach offers a holistic view of a recent environmental problems.

A series of workshops offers knowledge about bats and field work as well. At the closure of school year participants receive a diploma "Young friends of bats". The international women's day is traditionally celebrated by an exhibition of projects work which deals with ways of special housewife's activities performed in the past: ironing, laundry, sewing. Life along the river banks in the past and in the whole Biosphere Reserve is presented by the stories and other materials obtained from grandparents. Children and their parents are invited to attend a special event including excursion and fairy tale in the cave, which is organised in co-operation with Kosovel's library from Sezana each spring. In 2003 and 2004 the schools network received financial funds through the project Hidden Treasure which was organised by the Ministry of the Republic Slovenia for Schools and Sports. The project entitled "Wetlands from the mountain to the sea" was also supported by the Slovene National Commission for UNESCO and Ministry of Environment and Spatial Planning. Ramsar approved a CEPA programme of Park Škocjanske jame in 2005 through Small Grants Funds. This project "Network of karst wetlands people acting for wise use of wetlands" consists of a series of training for teachers in order to prepare a special education booklet about biodiversity and sustainable development. At the same time our experiences in educational programmes will be passed on to the Notranjska Regional Park, which will establish its own network around Cerknica Lake. Educational programmes are designed in order to achieve the following goals:

- To assure interdisciplinary approach in teaching and learning and thus raise public awareness about World Heritage Site and the MAB programme,

- To know the nature, social and historical aspects of the karst region and understand the proper way of implementing sustainable development,

- To participate in the formation of a new concept for economically oriented activities,

- To promote values of identity and connections among different cultures.

Park Škocjanske jame performs specially designed training for teachers from all of Slovenia and the network region as well.

In gaining new knowledge, practice and critical thinking, teacher training is a challenge proposed to establish the right attitude regarding place and space along with awareness of responsibilities.

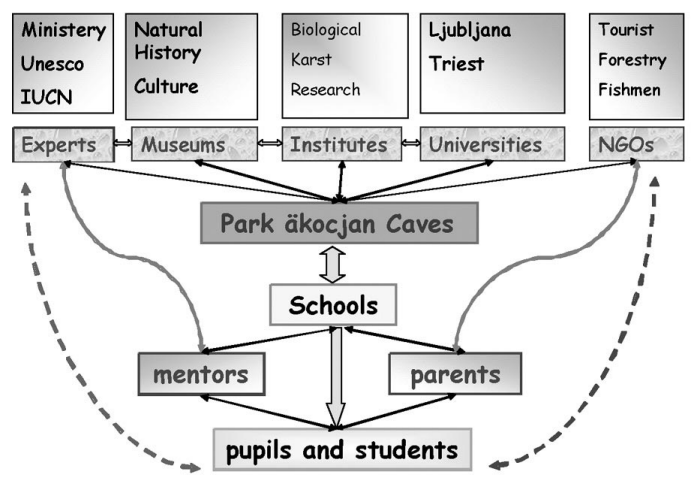

Figure 2: Interdisciplinary approach in research projects

The linear relationship between sustainable development and education: The UNESCO Word Education Report 1991 describes the needs for a "learning environment" which should be adjusted and allow continuous educating and training, effective technology transfer. The whole series of educational and training programmes should lead to the development of a competent individual. Such persons should be able to accept, use and adjust technology in a wise way by considering also local problems. Their knowledge, skills, attitude and ethical percep- 
tion will enable them to accomplish tasks in society. Knowledge and skills can be gained through an individual learning process, which should be based on proper and effective education and training. The methods and means should be constantly evaluated, institutions and teachers motivated (Van der Beken, 2002).

We can say that proper education is crucial for understanding the sustainable development, society and our place in it. The quality of knowledge gained and transmitted enables the sustainable development and rise in its quality.

Education should thus be oriented to learning as commitment with a strong tendency of understanding of basis of complex systems and relations among them (Bell, Cheung, 2002).

The international schools network of the park is trying to connect several aspects of individual problems, engaging many different experts and stakeholders in order to produce an outcome with practical applicability. This should result in everyday use of water, waste, energy, ecosystems services. The consequence is development and promotion of critical thinking and a responsible attitude (Debevec, 2005). It is important that such education is established at all levels. In times of fast accumulation of knowledge and information, we face the demands of presenting sustainable solutions of environmental problems with risk of disapproval, when in certain period of time they are proposed by a small group of experts and left to a general misunderstanding and lack of knowledge. Since sustainable development is a very responsible concept, many aspects should be considered in establishing the values system. Education in holistic approach should promote sustainability as a new value (Debevec, 2005).

In conclusion: Education and research projects in the park are designed in a way to enable the respective scientists and experts to transfer knowledge to young people. That is why special attention is paid to training teachers and personnel in the park. A summary of guidelines for achieving educational goals for work in schools network of the park:

- gain professional knowledge about natural, cultural features and people in the park,
- create an example for responsible attitude par excellence,

- motivation of non-governmental organisations for cooperation in programmes,

- recognise the importance of natural and cultural heritage and transfer of knowledge of world heritage.

In the future our educational programmes will be accomplished by activities from honey making to fruit processing, botany and zoology.

In December 2005 a centre of natural sciences will be opened in _kocjan. Archaeological, geological and biological collections will be demonstrated in a modern way in order to present the biodiversity and cultural heritage of protected area. The classroom with proper equipment will enable us to perform lectures and workshops for children and an adult audience.

With the MAB programme we will be able to connect conventions of UNESCO and Ramsar in projects where human presence and action in vulnerable ecosystems will be underlined.

Research work performed by school children are raised to the level of applicability of knowledge from books. Schools facilitate the presentation of problems and solutions to municipalities and other stakeholders.

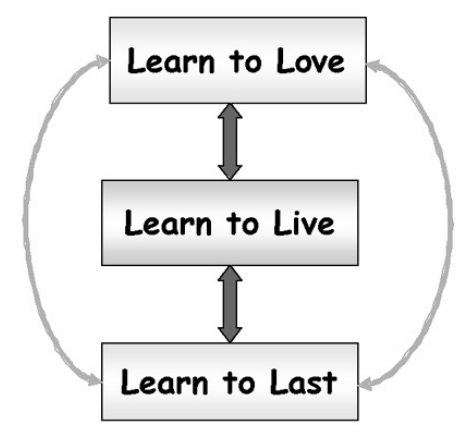

Education programmes are important for the creation of proper knowledge and awareness that natural and cultural heritage can be preserved only by living with it today - for tomorrow, in this place - for whole world.

The main answers to pedagogical questions about 
environmental education for sustainability and modest guidelines for future work in schools network of Park Škocjanske jame, Slovenija, are presented in formula $L \times 3 \mathrm{~L}$ : Learn to Love, Learn to Live, and Learn to Last (Debevec, 2005).

\section{BIBLIOGRAPY}

Bell V. J. D., Cheung Y.A. 2002. Introduction to sustainable development. V: Knowledge for sustainable Development. Encyclopedia of life support systems. Vol. 3. Badran A., Gobaisi A. D., Tayeb M. E., Tolna M. K., Sage A. P., Marchuk G. I., Johns A. T., Lundberg H. D., Szollosi-Nagy A., Chester G., Younes T., Dempsey J., Rao Prasada G., Sabouni R., Makkawi B., Woldai A., Agoshkoy V. I., Hornby R. J., Wall G., Watt H. M., Kotchetkov V., Al-Radif A., Sasson A., Bruk S. (ur.). Oxford, EOLSS: 411-440.

Debevec V. 2005.Park Škocjanske jame, Slovenija kraško podzemeljsko mokrišče in izobraževalni center. V: Novi izzivi za ohranjanje mokrišč v 21. stoletju. Beltram G. (ur.). Ljubljana, Ministrstvo za okolje in prostor: $58-62$.

Debevec V. 2003. Izobraževalni programi parka క̌kocjanske jame. Kras, 58 - 59: $40-41$.

Debevec Gerjevič V. 2003. Izobraževalni programi v parku Škocjanske jame. V: Zavarovana obmoð̌ja in njihov pomen za turizem. Morska učna pot. Mesečev zaliv in njegovi zakladi. Strunjan, 28. - 29. november 2003.Univerza na Primorskem, Koper: 66 -70 .

Debevec Gerjevič V. 2005. Mreža šol parka క̌kocjanske jame. V: Slovenija - vodna učna pot Evrope. Plut D., Bricelj M. (ur.). Ljubljana, Univerza v Ljubljani, Filozofska fakulteta, Oddelek za geografijo: $96-102$.

Novak B. 1990. Problemi vzgoje na pragu 21. stoletja. Sodobna pedagogika, Vol.3-4, No.112-238: 127125.

Van der Beken A. 2002. Water related education, training and technology transfer. V: Knowledge for sustainable Development. Encyclopedia of life support systems. Vol. 2. Badran A., Gobaisi A. D., Tayeb M. E., Tolna M. K., Sage A. P., Marchuk G. I., Johns A. T., Lundberg H. D., Szollosi-Nagy A., Chester G., Younes T., Dempsey J., Rao Prasada G., Sabouni R.,
Makkawi B., Woldai A., Agoshkoy V. I., Hornby R. J., Wall G., Watt H. M., Kotchetkov V., Al-Radif A., Sasson A., Bruk S. (ur.). Oxford, EOLSS: 459 - 483 